\title{
有楽町層粘土を用いた粘土の微視構造の 定量化手法に関する研究
}

\author{
児玉 潤1・足立 格一郎2 \\ 1学生会員 工修 芝浦工業大学大学院博士後期課程 工学研究科地域環境システム専攻 \\ （广108-8548 東京都港区芝浦3-9-14） \\ 2フェロー会員 Ph.D. 芝浦工業大学教授 工学部土木工学科（常108-8548 東京都港区芝浦3-9-14）
}

\begin{abstract}
自然堆積土は年代効果などにより微視的には粒子間結合が強く間隙が大きな構造を有しており，練り返 して再圧密した粘土よりも圧縮性が高い。このような微視構造の違いは電子顕微鏡などで定性的に示すこ とが可能であるが，定量的な評価を行う研究はあまり多くない，本研究では，有楽町層粘土を対象として 超哚度形状測定顕微鏡を用いた微視構造の観察・測定を行い, フラクタル次元と二次元フーリエ変換の 2 つの手法を用いて定量化解析を行った。 その結果, これらの手法は不摚乱試料と再構成試料の構造の違い や圧密前後の構造変化を定量的に示すことができ，自然粘土に対しても適用性が高いことが示された．ま た，空気乾燥法と凍結乾燥法による試料とでは，その定量的評価が異なることが確認された。
\end{abstract}

Key Words : clay, micro-structure, fractal dimension, fourier transformation,sample preparation

\section{1.はじめに}

粘土はその粒子サイズが非常に小さいことに起因し， 物理的作用のみならず様々な化学的作用をうける。 その ため, 堆積環境に応じて微視的には多種多様な構造を有 しており, 複雑な挙動を示す要因となっている.また, 粘土の様々な力学挙動を解明する際, 二次圧密やセメン テーション作用といった現象は, 有効応力概念を中心と した既往の理論ではその説明が難しいとされており,こ のような現象は沈下量予測などを難しくする．したがっ て, このような微視構造が力学挙動に与える影響を解明 することは非常に重要なテーマである.

近年の電子顕微鏡技術の飛躍的な進歩により, 粘土の 微視構造そのものを直接観察し，ミクロな視点から粘土 の力学挙動を解明することが可能となった。一般的には, 走査型電子顕微鏡（SEM）が用いられることが多く, 高 倍率になると粘土粒子同士の結合部まで確認することが できる. 数多くの研究によって, 電子顕微鏡で得られた 微視構造をもとにした力学挙動の定性的な評価手法が確 立されつつあり, このような粘土の微視構造の研究は粘 土の力学挙動の解明に不可欠な要素といえる.

沖積粘土や洪積粘土といった自然堆積土は，一般的に は年代効果やセメンテーション作用を受け，粒子間結合 力が大きく間隙が大きい構造を持った試料である。一方
で，この試料を練り返して再圧密した再構成試料は，そ れらの粒子閒結合が破壊され，間隙が小さくあまり構造 の発達していない試料であるといわれる. また, 再圧密 時に試料を高温環境におくことにより作成された高温再 構成試料は, 不摚乱試料に近い挙動を示すことが知られ ている.このような構造の差は, 圧密やせん断といった 力学挙動で明確に示されており, 電子顕微鏡による微視 構造の観察からもその要因をある程度特定することが可 能である.

このように, 自然粘土の堆積過程による構造の違いが 電子顕微鏡観察によってある程度定性的に示されるのに 対して，それらが “どの程度”異なるのか，あるいは 粘土の微視構造が “どの程度” 力学挙動に影響するのか, といった定量的評価についてはいまだ未解明な部分が多 い.これには, 走査型電子顕微鏡では微視構造の観察以 上のことが困難であることと, 微視構造の定量化に適し た手法が少ないことがその要因として挙げられるものと 思われる.このような微視構造の定量化に関する研究で は, 走査型電子顕微鏡で得られた画像をもとにパワース ペクトル分析を行った森脇, 和田の研究1) や, ペッドの 端部に着目して配向度を示した風間の研究2)において, 試料の構造の違いが定量的に示されており, 様々な研究 が進められている.

一方で, これらの問題を解決する手段として, レーザ 
一共焦点型顕微鏡（超深度形状測定顕微鏡）を用いた粘 土の微視構造の解明が注目されている。この方式の顕微 鏡は, 画質は電子顕微鏡に劣るものの, 微視構造の断面 を計測しデータ化することが可能で, 得られたデータを もとに断面の三次元表示などを行うほか，それらのデー 夕を用いた様々な定量化解析を行うことができる.

そこで，本研究では，試料として有楽町層粘土を用い て微視構造の観察・測定を行い, 定量化解析を行った. この際, フラクタル次元と二次元フーリエ変換の $2 つ の$ 手法を用いて定量化を行い, 圧密前後の構造変化を定量 的に示すことを試みた。

また, 顕微鏡試料の乾燥方法として, 空気乾燥法と凍 結乾燥法の $2 つ の$ 方法を用いた。これらの乾燥方法では 主に乾燥収縮の程度が異なるといわれ，一般的には凍結 乾燥法の乾燥収縮が小さいといわれている3 . 空気乾燥 法による試料を用いた微視構造の研究では, 竹内, 福江 の研究() や, 重松の研究5), 凍結乾燥法では鬼塚, 根上 の研究6) や利藤, 田中らの研究7) などがある. 一方, 乾 燥法の違いを検討したものでは姜, 土田の研究3) や引屋, 渡部の研究8), 風間の研究2), 廣野らの研究 る.

なお，構造の種類を示す用語として，本論文では綿毛 構造, 配向構造, ランダム構造という表現を用いる. こ こでのランダム構造は, 綿毛構造ほどペッド間の結合力 が大きくないが，配向構造ほど配向性も大きくない，綿 毛構造と配向構造の中間的な構造として位置づけている. これらの構造を持つ試料について, 图一1に示すように水 平方向と鉛直方向の 2 方向から断面を測定すれば, 綿毛 構造は粗さの度合いの差が小さい等方的な構造, 配向構 造は粗さの度合いの差が大きい異方的な構造といった具 合に構造の評価を行えるものと考えられる. また, 綿毛 構造, 配向構造といった構造モデルは基本的にはペッド の配列構造を示しており ${ }^{10)}$, 本論文で単に構造と述べ る場合は, 粘土粒子の凝集体 (ペッド) による構造をさ すものとする.

\section{2. 試験方法}

\section{(1) 試料の概要}

本研究では, 東京都大田区京浜島地下 $20.00 \mathrm{~m} \sim 21.00 \mathrm{~m}$ 付近でボーリング採取された試料を不擋乱試料として用 いた. この試料は採取された地層から一般的に有楽町層 粘土と呼ばれ，堆積年代などから沖積粘土に分類される. 主な物理特性は, 土粒子密度 $\rho_{\mathrm{s}}=2.711 \mathrm{~g} / \mathrm{cm}^{3}$, 液性限界 $\mathrm{w}_{\mathrm{L}}=97.0 \%$, 塑性限界 $\mathrm{W}_{\mathrm{P}}=45.4 \%$, 塑性指数 $\mathrm{I}_{\mathrm{P}}=51.6$ であ る. また, 試料の構造の違いを検討するため, この試料

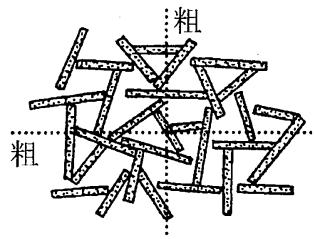

(a) 綿毛構造

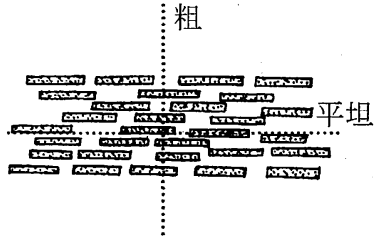

(b) 配向構造
図-1 粘土の構造モデルと粗さの評価 (文献 10）に加筆)

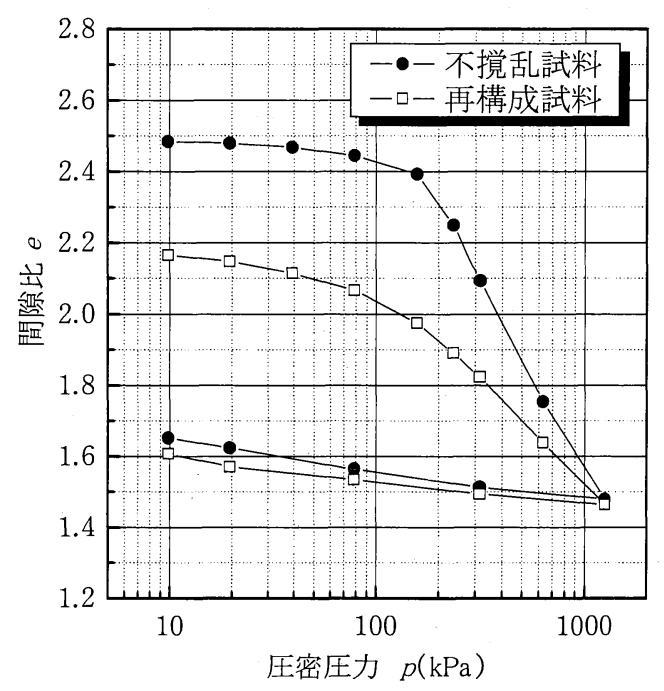

図-2 段階裁荷圧密試験結果

を425 $\mu \mathrm{m}$ ふるいで裏ごしして一旦練り返し，液性限界の 1.5倍程度の含水比になるように蒸留水を加えてスラリ 一状態にした後, 再圧密することで作成した再構成試料 も用いることとした．再構成時の載荷は $10 \rightarrow 40 \rightarrow 90 \rightarrow$ $182(\mathrm{kPa})$ の段階載荷とし, 最終荷重のみ3t線に到達し た時点で圧密を打ち切り, それ以外は24時間載荷とした。 なお, 再構成時の最終荷重 $182 \mathrm{kPa}$ 和不擋乱試料の圧密試 験によって得られた圧密降伏応力と同値である.

\section{（2）段陵裁荷圧密試験}

不擋乱試料の圧密降伏応力の決定と, 上記の 2 種類の 試料の微視構造と力学挙動との関連を検討するため, 本 研究では段階裁荷圧密試験を行った. 載荷荷重は, 事前 の調査により圧密降伏応力が200kPa前後であることが予 想されたため, その前後の載荷段階にもう1段階荷重を 加えた $9.8 \rightarrow 19.6 \rightarrow 39.2 \rightarrow 78.4 \rightarrow 156.8 \rightarrow 235.4 \rightarrow 313.6 \rightarrow$ $627.2 \rightarrow 1254.4(\mathrm{kPa})$ の9段階で行い, 除荷した後解体し た試料を圧密後試料として顕微鏡測定に用いた.

図一2に段階裁荷圧密試験結果を $e-\log p$ 曲線として示 す. セメンテーション作用などにより粒子間結合が強く 
高位な骨格構造を有している不擋乱試料は，初期段階の 間隙比も大きく, 明確な降伏点を示している. 一方の再 構成試料は練り返しによってそれらの構造が破壊され， 粒子間結合力が弱い低位な骨格構造であるため, 不擋乱 試料に比べて初期段階の間隙比が小さく, 明確な降伏点 を示すことなく漸増的に圧密が進行している，また，圧 密前後では不擋乱試料の間隙比の変化が大きいことから, 圧縮性が高く構造が大きく変化していることが示されて いるが, 圧密後の間隙比は再構成試料とほぼ一致してお り, 圧密後の状態を間隙比のみで判断すると, 両試料の 微視構造にそれほど違いが見られないことを伺わせる.

\section{（3）顕徽鏡の測定方法}

本研究では, 粘土の微視構造の観察・測定に超深度形 状測定顕微鏡とよばれるレーザ一共焦点型顕微鏡（光学 式顕微鏡）を用いるものとした. 顕微鏡での測定条件を 表ー1に示す．試料の測定場所については，測定箇所を 特定後, 試料の位置を変えることなくレンズのみを切り 替える形で測定するものとした．断面形状はどの倍率も 共通で1024×768（個）のデータに分割して測定され， $\mathrm{x}$ 方向, $\mathrm{y}$ 方向のデータ間隔は倍率に反比例して小さくな る. 測定ピッチは高さ方向（z力向）の測定精度を示し ており，レンズ倍率に応じて変化させている，また，本 研究ではレンズ倍率を測定倍率として示しており, 倍率 200倍と400倍はそれぞれ100倍レンズの光学ズーム2倍と 4倍を示している.

顕微鏡による観察および測定は圧密前試料（自然試 料）と圧密後試料について行った. 顕微鏡試料作成の際 の乾燥法は以下の2種類とした ${ }^{11)}$.

(1)空気乾燥法 : 試料をあらかじめ $10 \times 10 \times 20 \mathrm{~mm}$ 程度の直 方体に成形し，真ん中に切れ目を入れ3〜7日ほど常温 で自然乾燥させる. その後, 試料を切れ目から手で割 り，その断面を測定断面とした.

(2)凍結乾燥法 : 試料を $5 \times 5 \times 10 \mathrm{~mm}$ 程度の棒状に成形した 後, 液体窒素の中で瞬間的に凍結させる. 凍結が落ち 着いたところで液体窒素から試料を取り出し, ペンチ などでたたいて割った後, 真空状態で1日程度脱気を 行い試料の水分を昇華させることで乾燥させ，割れた 面を測定断面とした.

なお，凍結乾燥法では試料サイズが大きい場合，凍結 時の水の体積膨張の影響により，ひび割れを生じやすく なる. そのため, 自然乾燥法の試料よりも成形時の大き さを上記のように一回り小さくした.

試料ごとに最大主応力面に対して水平な断面（水平断 面 : H断面）と, 垂直な断面（鉛直断面 : V断面）の2方 向の断面を測定し, 試料の構造の違いを検討した. 測定 断面数は各試料, 各断面ともに5断面ずつ測定し, 測定
表-1 顕微鏡の測定条件

\begin{tabular}{c|c|c|c|c}
\hline 測定倍率 & \multicolumn{2}{|c|}{ 測定範囲 } & 測定間隔 & 測定ピツチ \\
\hline$($ 倍 $)$ & 縦 $(\mu \mathrm{m})$ & 横 $(\mu \mathrm{m})$ & $(\mu \mathrm{m})$ & $(\mu \mathrm{m})$ \\
\hline 10 & 1479 & 1109 & 1.457 & 0.5 \\
\hline 20 & 739 & 554 & 0.728 & 0.2 \\
\hline 50 & 295 & 221 & 0.291 & 0.1 \\
\hline 100 & 147 & 110 & 0.146 & 0.05 \\
\hline 200 & 73 & 55 & 0.073 & 0.05 \\
\hline 400 & 37 & 28 & 0.036 & 0.05 \\
\hline
\end{tabular}

された断面は断面の傾き補正とノイズの除去等の処理を 行った後, 解析に用いた.

\section{3. 解析手法}

\section{（1）フラクタル次元 ${ }^{12 ， 13)}$}

フラクタル次元とは, 断面全体の複雑さを定量的に表 すパラメータである.ここでいう「フラクタル」とは, 部分と全体が相似な関係を持っているような関係（自己 相似性）を有するような構造のことを指し，これに「次 元」の概念を当てはめることで，その断面の複雑さを表 わすものである. フラクタル次元を直線に当てはめると 1(一次元), 凹凸の全くない完全な平面では2（二次元） になり，凹凸が多く粗い断面になるほどフラクタル次元 が大きくなる.

面を扱う場合のフラクタル次元を求める式は対数式で 以下のように表わされる.

$$
\log \left(\eta^{2}\right)=\log S_{0}-\left(\frac{D}{2}-1\right) \log \eta^{2}
$$

ここで, $\eta$ はメッシュ間隔, $S\left(\eta^{2}\right)$ はメッシュ間隔 $\eta$ で測定した場合の測定断面積, $S_{0}$ は定数, そして $D$ が求めるフラクタル次元である. この式に従い, 求めた い断面についてメッシュ間隔 $\eta$ で高さデータを計測し， そのときの断面全体の表面積を求める. このメッシュ間 隔を何段階かに変化させ，そのときの面積 $S\left(\eta^{2}\right)$ を測 定すれば $\log S\left(\eta^{2}\right)$ と $\log \eta^{2}$ の間に線形関係が認めら れる. その勾配 $k$ を最少 2 乗法によって求め, 以下の式 によりフラクタル次元 $D$ が得られる.

$$
k=-\frac{D-2}{2}
$$

解析範囲は各測定倍率共通でデータ数で $256 \times 256$ とし, 1断面を12個の領域に分割する.したがって，5断面で60 
個のフラクタル次元の值を平均したものを結果として用 いている. フラクタル次元を求める際のメッシュ間隔 $\eta$ ほ $1 ， 2 ， 4 ， 8 ， 16 ， 32 ， 64 ， 128$ ，256の9段階とした.

\section{（2）二次元フーリエ変換 $\left.{ }^{14)}, 15\right)$}

二次元フーリエ変換とは, 一次元フーリエ変換の概念 を二次元，すなわち平面に対して拡張したもので，一定 間隔で刻まれる変動波形を低周波から高周波まで，ある 範囲の周波数毎に分解してそれぞれの強度 (パワースペ クトル）を求め，その周波数分布から与えられた波形の 特徵を見出す解析手法である. 断面形状の值は座標 $f(x, y)$ で与えられ，一般的には次式が用いられる.

$$
\begin{aligned}
& F(m, n)=\int_{-\infty}^{\infty} \int_{-\infty}^{\infty} f(x, y) e^{-2 \pi(m x+n y)} d x d y \\
& \text { ここに, } m: x \text { 軸方向の空間周波数 } \\
& n: y \text { 軸方向の空間周波数 } \\
& j=\sqrt{-1}
\end{aligned}
$$

ただし, この式の変換後の周波数 $F(m, n)$ は連続量 $f(x, y)$ に対する積分で与えられており, 離散量では 二次元離散フーリ工変換の係数 $C(m, n)$ は次式で与え られる。

\section{$C(m, n)$}

$=\frac{1}{M N} \sum_{k=0}^{K-1} \sum_{l=0}^{L-1}\left\{f(k d x, l d y) e^{-2 \pi j\left(\frac{m k d x}{M}+\frac{n l d y}{N}\right)}\right\} d x d y$

ここに, $M: x$ 軸方向の測定範囲

$N: y$ 軸方向の測定範囲

$d x: x$ 軸方向の測定間隔

$d y: y$ 軸方向の測定間隔

$K: x$ 軸方向の測定点数

$L: y$ 軸方向の測定点数

$k$ : 測定データの $x$ 軸方向の測定番号

$$
(k d x=x)
$$

$l:$ 測定データの $y$ 軸方向の測定番号

$$
(l d y=y)
$$

この二次元フーリエ変換により $f(x, y)$ は $C(m, n)$ の周波数分布に変換される（図一3）. すなわち，断面 の傾きやうねりといった波長の長い緩やかな変化は低周 波, それよりもかなり波長の短い細かい凹凸の変化は高 周波として, 空間周波数ごとに表現される.ただし，こ こでいう空間周波数 $1 \mathrm{~Hz}$ とは，例えば，解析範囲が $5 \mu \mathrm{m}$ の場合には $5 \mu \mathrm{m}$ 周期とする正弦波を表している.

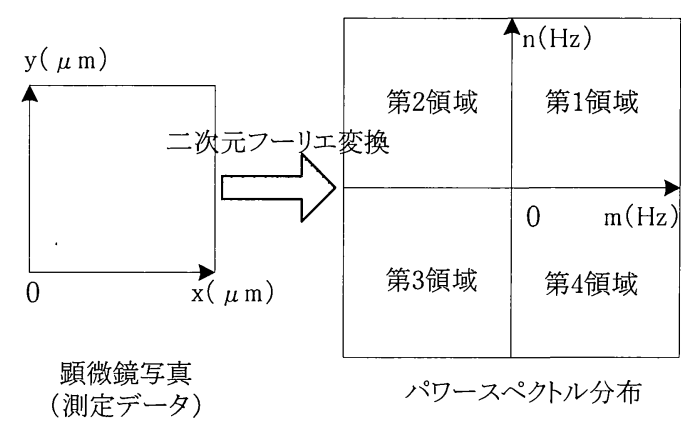

図一3 二次元フーリエ変換の概念

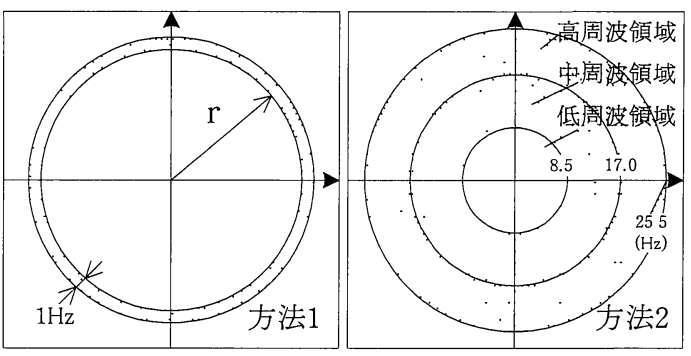

図-4 定量化手法の概念図

表-2 各測定倍率での解析範囲

\begin{tabular}{c|ccc}
\hline 測定倍率(倍) & \multicolumn{3}{|c}{ 波長 $(\mu \mathrm{m})$} \\
\hline$\frac{10}{20}$ & 371.41 & $\sim$ & 14.86 \\
\hline 50 & 185.70 & $\sim$ & 7.43 \\
\hline 100 & 74.28 & $\sim$ & 2.97 \\
\hline 200 & 37.14 & $\sim$ & 1.49 \\
\hline 400 & 18.57 & $\sim$ & 0.74 \\
\hline & 9.29 & $\sim$ & 0.37 \\
\hline
\end{tabular}

解析範囲はフラクタル次元と同様に各倍率共通でデー 夕数で $256 \times 256$ 個とした. 本研究で用いた解析ソフトで は，このデータ範囲の場合には両軸とも0～ $25.5 \mathrm{~Hz}$ 空 間周波数分布として0.1Hz刻みで得られる。これを $\mathrm{x}$ 軸が 正の領域において 域）と負方向（0〜-25.5Hz:第4領域）の2つの領域に対 して行った. 空閒座標系の第2領域は第4領域と, 第3領 域は第1領域と対称で，全く同じデータが得られるので, 得られた值を等倍している.

ただし，得られたパワースペクトル分布はそのままで は定量化解析に用いることができないため，パワースペ クトル分布を用いて以下の $2 つ の$ 評価方法で定量化を行 った (図一4参照) .

(1)方法1 : パワースペクトル分布の原点からの距離を $\mathrm{r}$ と し，その距離でのパワースペクトルの総和を $0 \sim 25.5 \mathrm{~Hz}$ まで1Hz間隔で求める. 


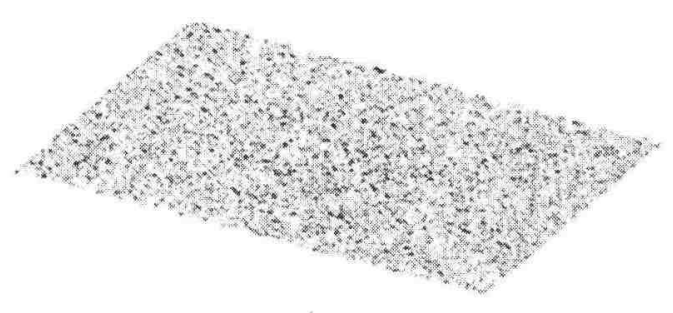

(a) やすり $0.5 \mu \mathrm{m}$

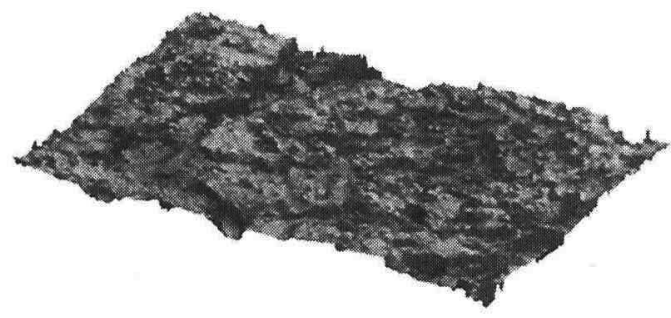

(b) やすり $9 \mu \mathrm{m}$

图-5 やすり断面の三次元表示 (100 倍)

(2)方法2 : パワースペクトル分布を, 低周波領域（0〜 8. $5 \mathrm{~Hz})$ ，中周波領域（8.5 17.0Hz），高周波領域 (17.0〜25.5Hz) の3つの領域に3等分し，それぞれのパ ワースペクトルの総和を求める.

方法1の結果はどの測定倍率でも周波数で1〜25Hzまで 得られるが，それぞれの倍率で波長が異なる（測定倍率 10倍の $1 \mathrm{~Hz}$ の波長は測定間隔 $\times$ データ数 $=1.457 \mu \mathrm{m} \times 255$ 個 $=371 \mu \mathrm{m}$, 測定倍率 100 倍での $1 \mathrm{~Hz}$ の波長は0.146× 255=37 $\mu \mathrm{m}$ である）.そこで, 表一2にしたがって周波数 を波長に変換し, 各測定倍率で得られたパワースペクト ル曲線を1つの図に合成して示すものとした．なお，測 定倍率が大きくなるほど波長は小さくなるため, この合 成図では図の右側に行くほど横軸の值が小さくなること に留意されたい。図の横軸における371，37，3.7，0.37 $\mu \mathrm{m}$ の值は, 測定倍率10倍の $1 \mathrm{~Hz}$ 基準にした場合, それ ぞれ1，10，100，1000Hzに対応する. また，方法1, 方 法2のどちらにおいても，一般的にパワースペクトル総 和が大きいほど粗い断面であると評価できる.

解析結果は, フラクタル次元と同様に1断面につき 12 個のデータが得られるので，各試料5断面より60個のデ 一タが得られ，それらを平均した值を結果として示すも のとした.

\section{（3）人エモデル解析}

上記の2つの定量化手法の特性を確認するため, 精密 研磨シート（やすり）を人工モデルとして断面の定量化 解析を行った. これは, フィルムシートに所定の粒子サ イズの研粒を吹きつけたもので，今回は表記 $0.5 \mu \mathrm{m}$ と9

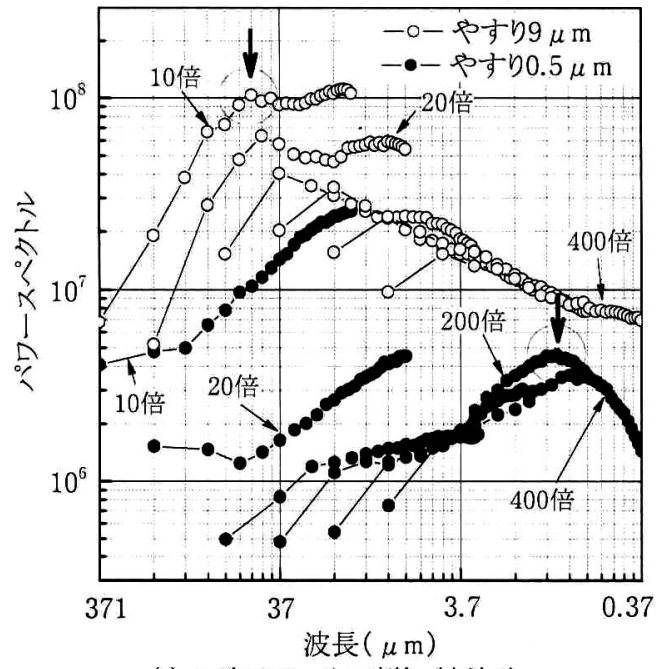

(a) 二次元フーリエ変換（方法1）

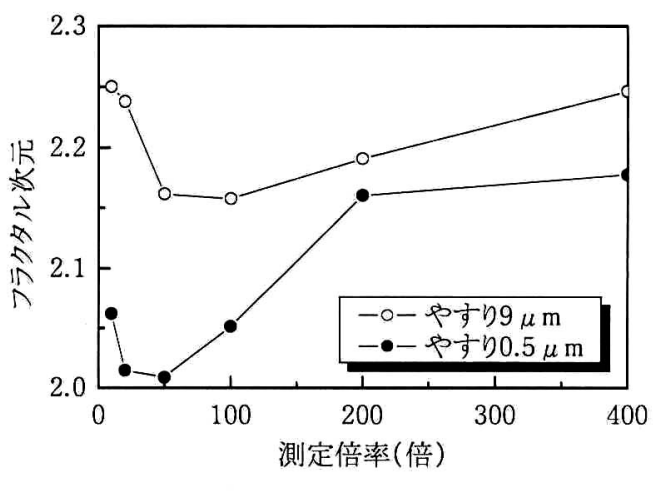

(b) フラクタル次元

图一6 人工モデルの定量化解析結果

$\mu \mathrm{m} 22$ 種類のやすりの結果を示す. 図一5には2つのやす りの測定倍率100倍での断面を三次元表示で示している. 均一ではないものの, 表記どおりやすり $9 \mu \mathrm{m} の$ 断面の凹 凸が大きく粗い断面であるのがこの図からわかる.

二次元フーリエ変換の方法1による結果と, フラクタ ル次元の解析結果を图一6に示す. 各測定倍率で得られ るパワースペクトル曲線は合成することにより良い一致

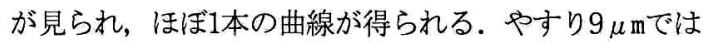
波長 $50 \mu \mathrm{m}$ ，やすり $0.5 \mu \mathrm{m}$ では波長 $1 \mu \mathrm{m}$ 前後でピーク部 分が得られており，ピークを挟んで右上がりの曲線から 右下がりの曲線へ推移する。すなわち, 表記とは完全に 一致しないものの，それぞれのやすりの目の粗さに対応 した波長でピークが得られるのがわかる. 一般的に凹凸 の幅（波長）が小さくなるほど，凹凸の大きさ（振幅） も小さくなるため, ピーク部分も図の右下方向へと移動 する.

また, フラクタル次元に着目すると, やすり $9 \mu \mathrm{m}$ は測 定倍率10倍でフラクタル次元がかなり大きく, 測定倍率 
が大きくなるほど值が減少し再び増加する，一方のやす り $0.5 \mu \mathrm{m}$ は測定倍率10倍ではフラクタル次元が低く, 測 定倍率が大きくなるほどフラクタル次元が大きくなる. どちらのやすりも二次元フーリエ変換における方法 1 で 得られたピーク部分では, フラクタル次元もかなり大き くなっており，2つの定量化手法でよい対応が見られる. すなわち，フラクタル次元を「断面の凹凸の形状がは っきりと認識されるときフラクタル次元も大きくな る」と定義すれば, 二次元フーリエ変換の方法 1 でピー クが得られる測定倍率ではその断面に支配的な凹凸が得 られ，それよりも測定倍率が大きくなると凹凸の一部分 が捉えられるため, フラクタル次元が小さくなるという 性質を持つと考えられる. したがって, や寸り $9 \mu \mathrm{m} の$ 場 合は測定倍率10倍がその断面の粒子による凹凸の評価に 最適な倍率であり, それよりも大きい倍率では粒子表面 の凹凸が評価されるといえる. 一方のやすり $0.5 \mu \mathrm{m}$ は測 定倍率200倍程度で粒子による凹凸が得られ，その倍率 が粒子による凹凸の評価が得られる最適倍率であるとい える.

また, 様々な解析により, 測定倍率をさらに大きくし た場合には，理論的には図一7に示すようにパワースペ クトル曲線では小さなピークが続き, フラクタル次元も それにあわせて上下を繰り返す可能性が高いと考えられ る.これを粘土の微視構造の評価に当てはめた場合には, ペッド, 粒子, 粒子表面の凹凸, といった具合に変化し， その最大のピークの倍率が構造の基本単位に忍じた最適 な測定倍率であるという評価ができるものと考えられる.

\section{4. 解析結果}

\section{（1）試料の断面形状}

不擋乱試料と再構成試料について, 図一8に空気乾燥 法と凍結乾燥法の圧密前試料の代表的な断面写真とその 三次元表示断面を示す. 空気乾燥法による試料の断面を 見ると，不擋乱試料は粘土粒子の塊の間に大きな空間が 存在しており，かなり間隙が大きく粗い印象の断面で, 珪藻などの不純物も数多く確認することができる，再構 成試料は裏ごしによって大型の珪藻が取り除かれている ため，小さい珪藻が若干見られるもののほぼ均一な試料 であり, 不擋乱試料に比べて粗さの度合いが低い断面で あることがわかる。 また, 凍結乾燥法の試料は, どちら の試料も非常に平坦な断面が得られており，不擋乱試料 では断裂した珪藻や砂粒子などが確認できる．したがっ て, 乾燥法によって試料の割れ方がかなり異なるといえ る.

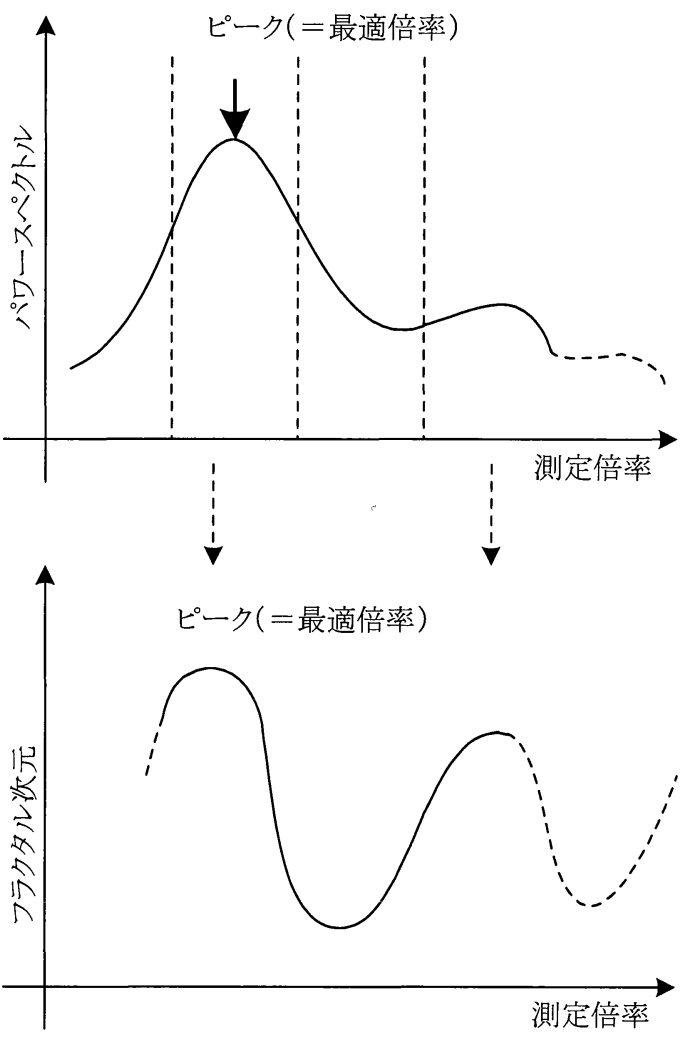

图-7 二次元フーリエ変換とフラクタル次元

\section{（2）フラクタル次元による解析結果}

不擋乱試料および再構成試料の圧密前後のフラクタル 次元の解析結果を図一9に示す．空気乾燥法の試料の結 果に着目すると，圧密前ではほぼどの測定倍率でも不擋 乱試料のフラクタル次元は再構成試料に比べて大きく, 再構成試料に比べて水平断面, 鉛直断面ともに粗い断面 であるのがわかる、特に測定倍率が大きくなるほどその 差が明確に現れる. 不摚乱試料は水平断面, 鉛直断面と もほぼ同じ值を示しており，どちらも再構成試料に比べ て粗さの度合いが大きいことから，等方的な綿毛構造に 近い構造であることがこの結果から評価できると考えら れる.

一方で, 再構成試料のフラクタル次元も水平断面と鉛 直断面ともにほぼ同じ值を示している. しかし，不撹乱 試料に比べ相対的に值が小さいことから，配向構造とは 呼べないものの, 粒子間結合が弱く構造があまり発達し ていないランダム構造的なものであると考えられる.

圧密後は，どの試料のフラクタル次元もほぼすべての 測定倍率で小さくなる．その減少量は鉛直断面よりも水 平断面の方が大きく, 圧密後は不擋乱試料, 再構成試料 ともに水平断面よりも鉛直断面の值が大きくなる．した がって, 不擋乱試料, 再構成試料ともに, 圧密により水 

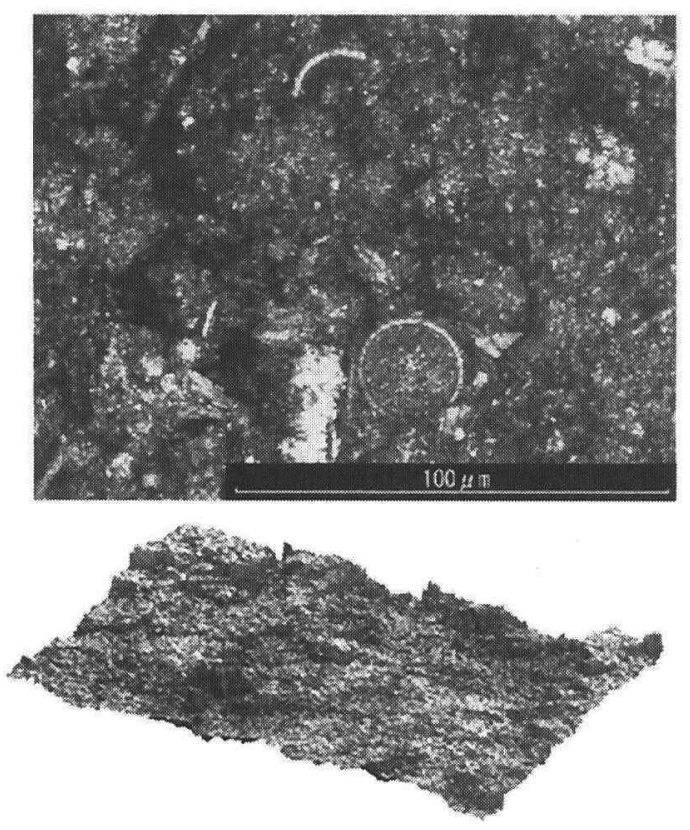

(a) 不擋乱試料 : 空気乾燥
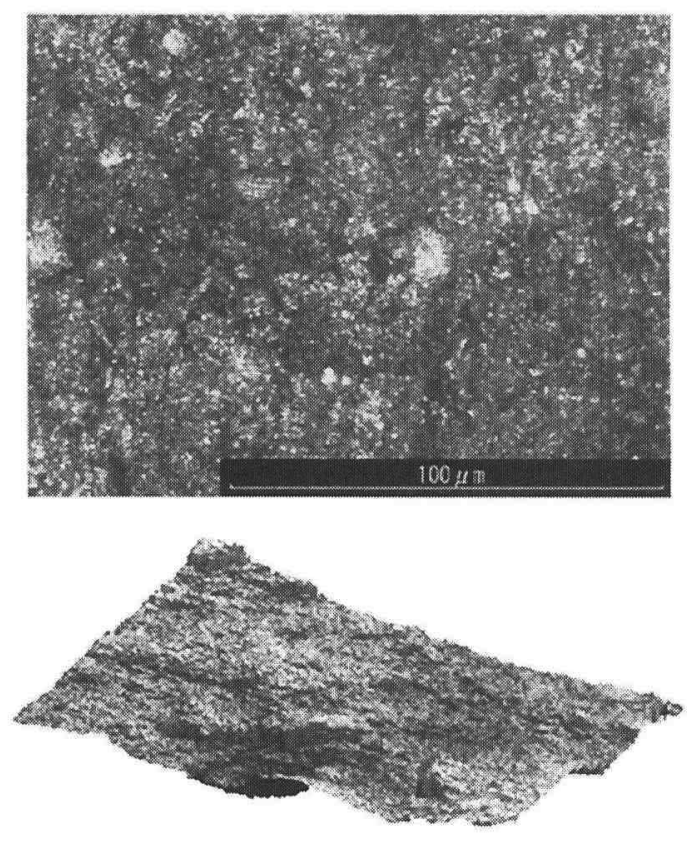

(c) 再構成試料 : 空気乾燥
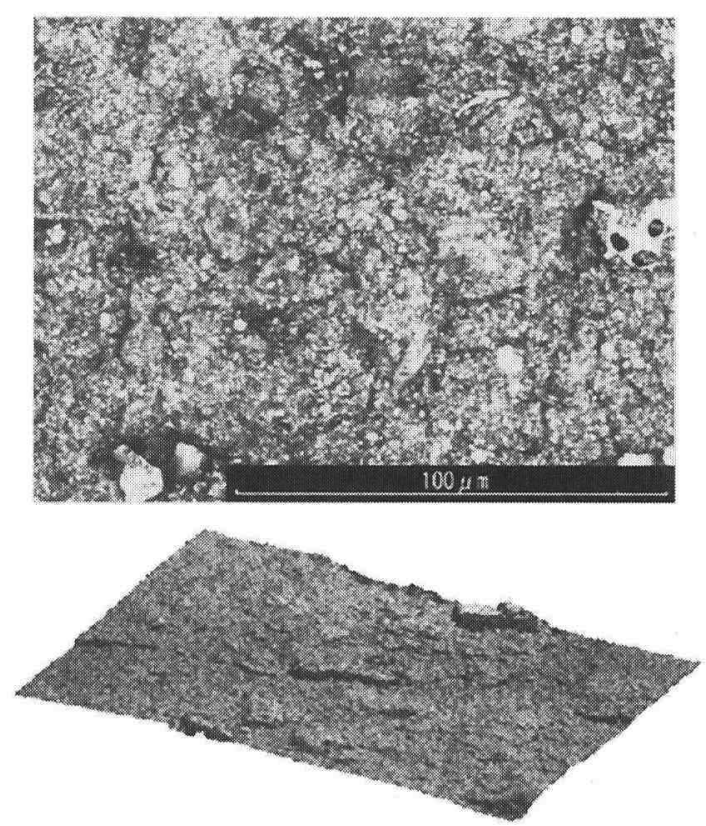

(b) 不摚乱試料：凍結乾燥
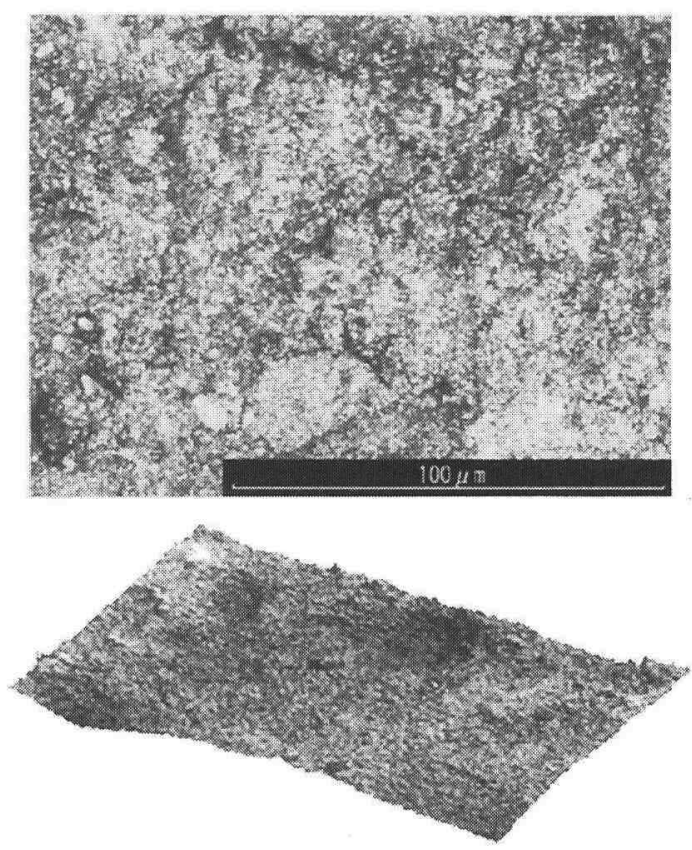

(d) 再構成試料 : 凍結乾燥

图-8 圧密前の各試料の断面形状（水平断面, 測定倍率 100 倍)

平断面が平坦で鈶直断面が粗い配向構造的なものに構造 が変化したものと評価できる．また，フラクタル次元の 変化量は再構成試料よりも不摚乱試料で大きい. 圧密試 験結果でも不摚乱試料の間陌比変化が大きいことから,
不摚乱試料の構造の変化の度合いが定量的に示されてい るものと考えられる.

また, 測定倍率200倍での結果を抽出し, 圧密前後で 比較したものを图一10に示す．圧密前の状態では不摚乱 

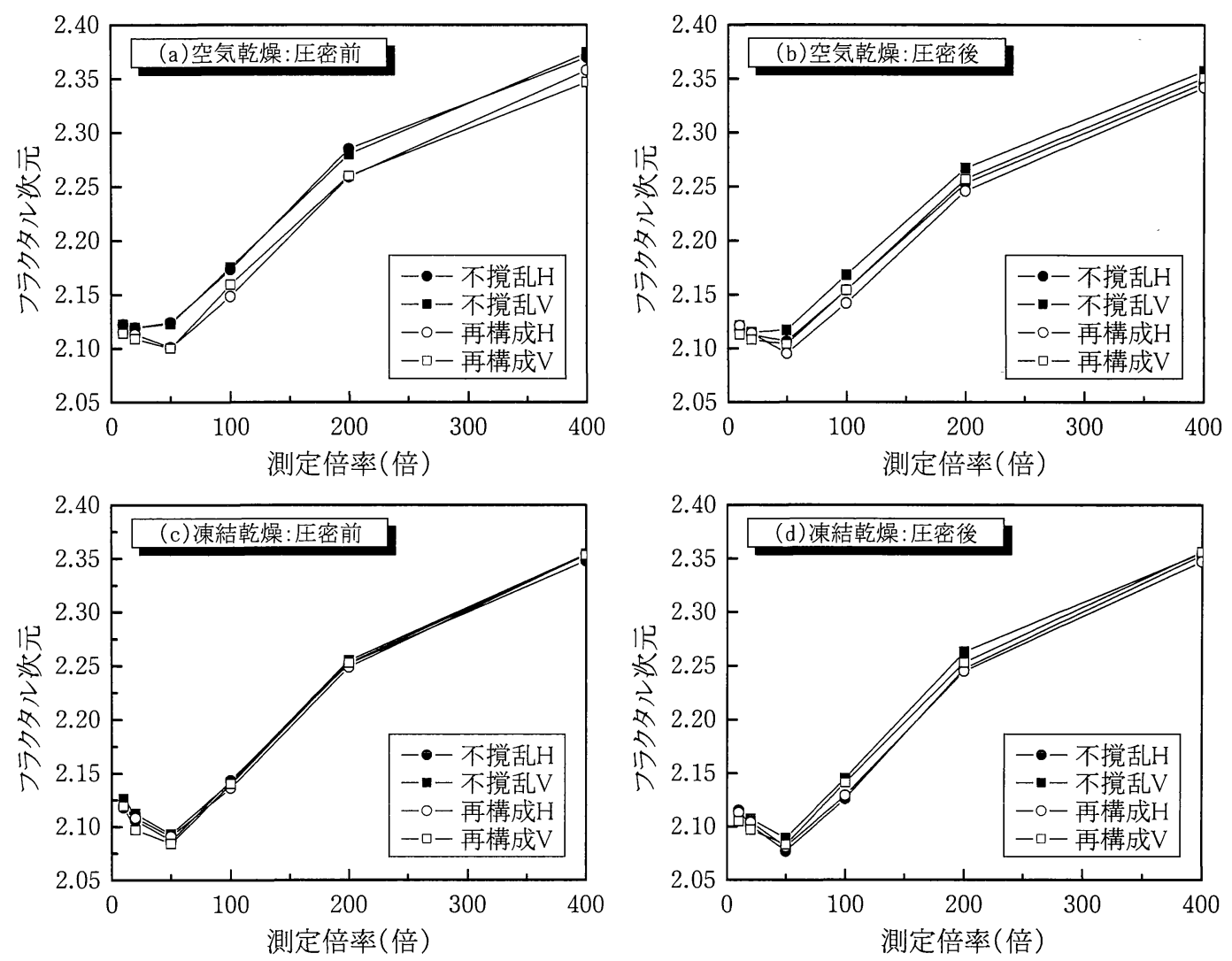

图一9 フラクタル次元解析結果
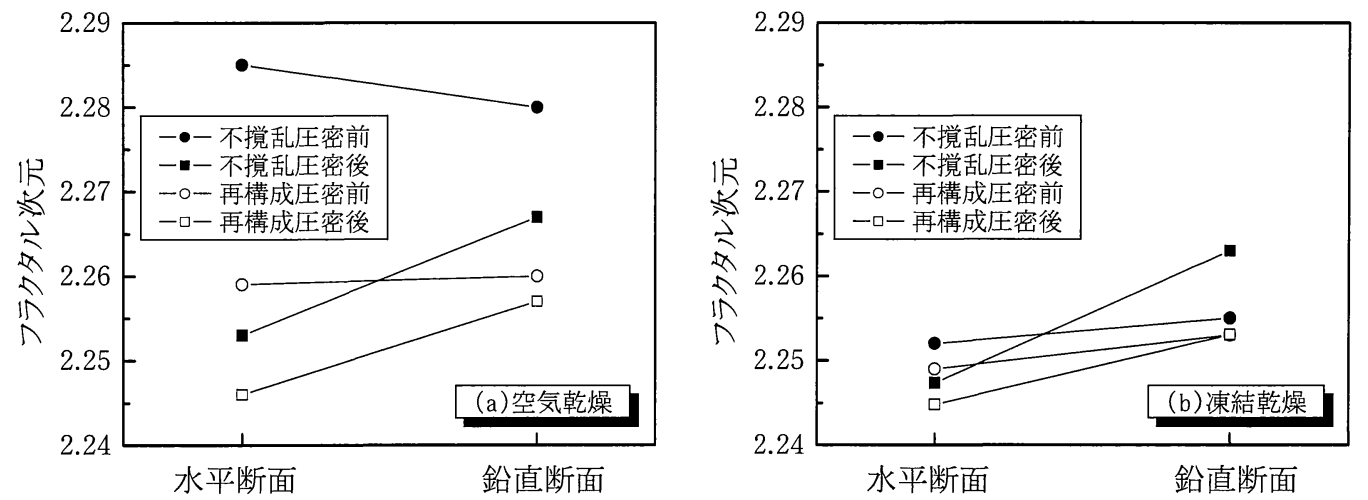

図-10 測定倍率 200 倍での圧密前後のフラクタル次元

試料，再構成試料とも，水平断面と鉛直断面に明確な関 係は見られないが，圧密後は両試料とも水平断面が鉛直 断面に比べて相対的に小さくなっており，配向性が顕著 に現れるのがわかる.

ただし，圧密後においても不擋乱試料と再構成試料と では完全にフラクタル次元が一致しない.これは, 完全 に粒子間結合が破壊された再構成試料の圧密と異なり, 不擋乱試料は圧密後もある程度の粒子間結合力を有して
いるため, フラクタル次元が若干大きくなるものと考え られる。

一方で, 凍結乾燥法の試料のフラクタル次元は空気 乾燥法の断面に比べて全体的に小さく, 平坦な印象にあ った断面の結果が得られている。このようなフラクタル 次元の減少は不摚乱試料で大きく, 圧密前の状態では不 擋乱試料と再構成試料ともフラクタル次元がほぼ同じで, 明確な違いがみられなくなる．ただし，圧密後のフラク 

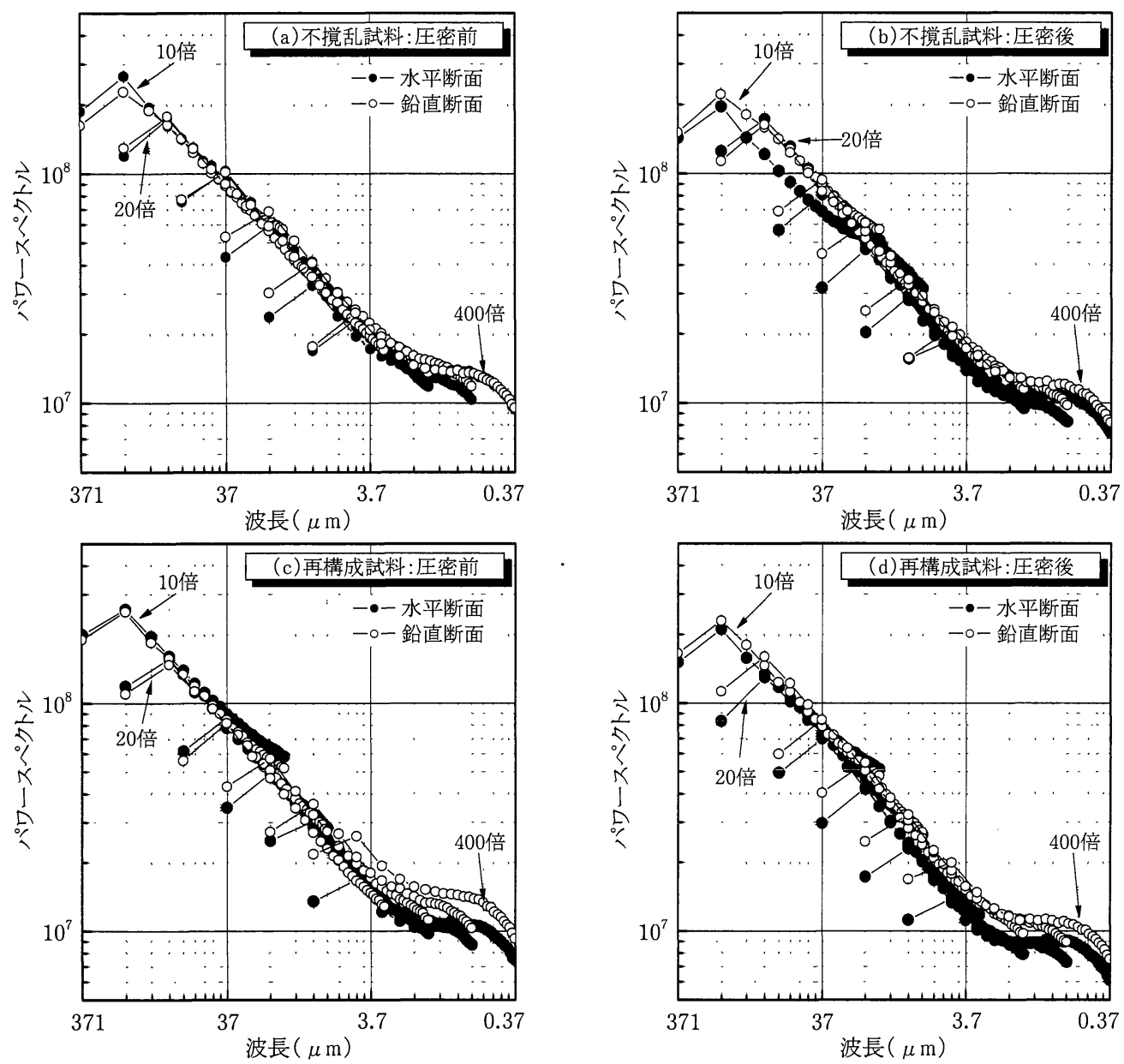

図一11 方法 1 による二次元フーリエ解析結果（空気乾燥試料）

タル次元では, 凍結乾燥試料でも水平断面のフラクタル 次元が鉛直断面に比べて小さいという結果が得られてお り, 空気乾燥試料と同様に配向的な構造に変化したと評 価できるものと考えられる.

\section{（3）二次元フーリエ変換による解析結果}

空気乾燥試料および涷結乾燥試料の二次元フーリエ変 換の方法1による結果をそれぞれ図ー11，図ー12に示す。 人工モデルのように平坦な面に粒子の凹凸が均等に分布 している場合と異なり, 粘土の断面は様々なサイズのう ねりを生じているため, 方法1では明確なピークを示す ことなく,すべての試料でほぼ右下がりのパワースペク トル曲線を描いているのがわかる。

空気乾燥試料の結果を見ると, 圧密前では不摚乱試料 は水平断面と鉛直断面のパワースペクトル曲線がほぼ一 致し, 粗さのほぼ等しい等方的な構造であることが示さ れている. 一方の再構成試料は波長の小さい部分で水平
断面よりも鉛直断面のパワースペクトル曲線が大きくな っており, 水平断面よりも鉛直断面が粗い配向的な構造 であることを示していると考えられる. また, 測定倍率 400倍では再構成試料の鉛直断面のパワースペクトル曲 線が不擋乱試料に近くなるものの, 全体的に不擋乱試料 のパワースペクトルは再構成試料よりも大きく, 比較的 粗い断面であることがこの図からわかる.

圧密後は不擋乱試料, 再構成試料ともに全体的にパワ 一スペクトルが下がっており, 特に水平断面の減少量が 大きい. そのため, 不擋乱試料は水平断面が平坦で, 鉛 直断面が粗い配向的な構造に変化し, 再構成試料も圧密 前に比べて，ほぼすべての波長で明確に水平断面と鉛直 断面との差が現れていることから, 圧密前に比べてより 構造の配向性が高まったものと評価できる.

一方, 凍結乾燥試料の結果を見ると, やはり不摚乱試 料, 再構成試料ともに右下がりのパワースペクトル曲線 を示しているが, 空気乾燥試料と比較すると, 全体的に 

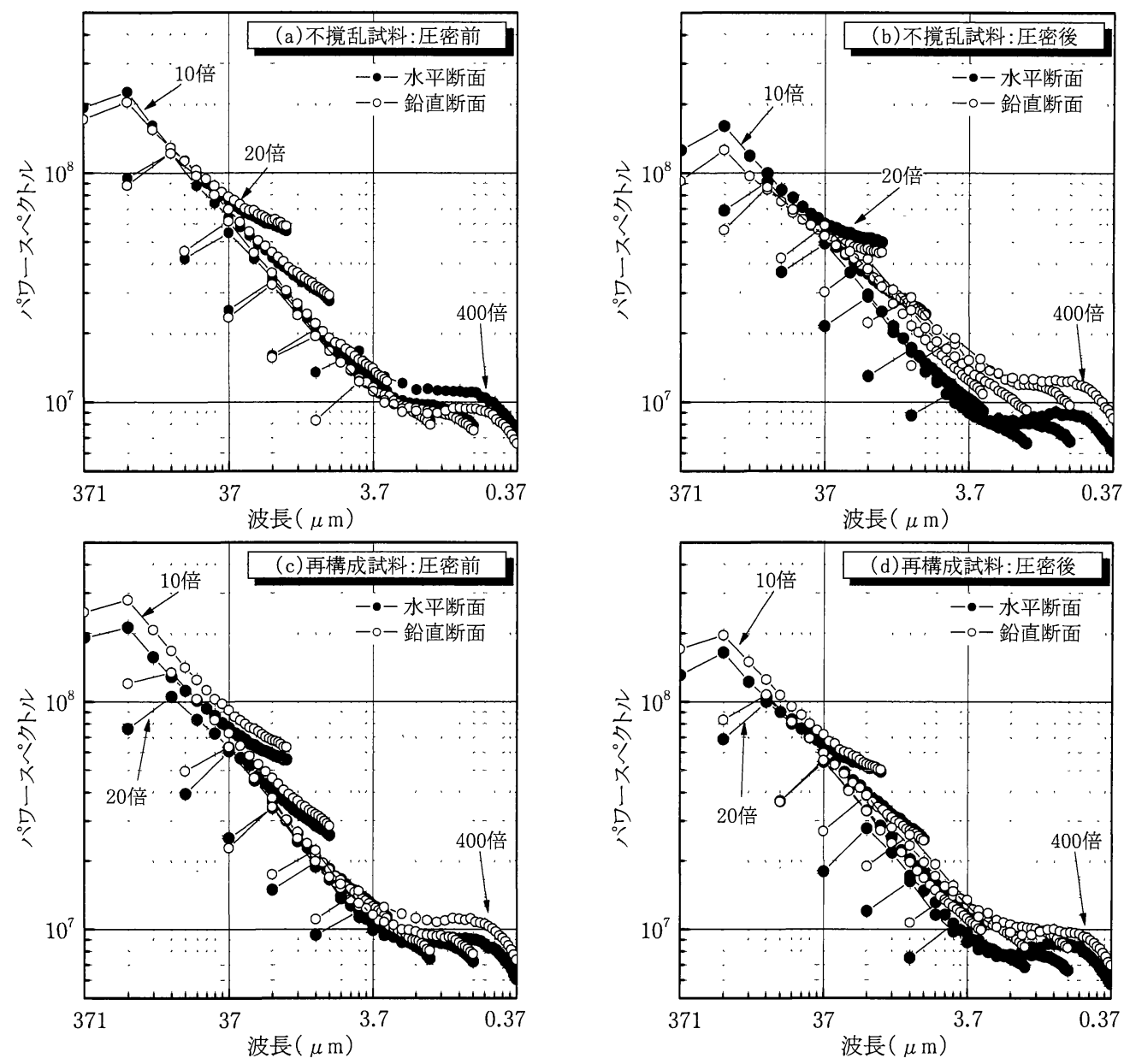

図-12 方法 1による二次元フーリエ解析結果（凍結乾燥試料）

パワースペクトルが小さくなっており，とくに波長 $37 \mu$

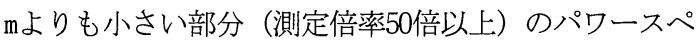
クトルの值が小さくなる.これは, 空気乾燥試料に比べ て平坦な断面が得られていることを示しており，パワー スペクトル曲線の勾配の小さい部分の幅も空気乾燥試料 に比べて長くなっているのがわかる.また，このような 傾向はフラクタル次元で得られた結果とほぼ一致する.

圧密前についてみると, 空気乾燥試料と同様に不撹乱 試料は水平断面と鉛直断面の值がほぼ等しい等方的な構 造であることを示しており, 再構成試料は水平断面の值 が若干低くランダム構造的なものであることを示してい る.一方, 圧密後はやはり不撹乱試料, 再構成試料とも に水平断面と鉛直断面のパワースペクトルの差が大きく なり, 配向的な構造に変化していることが示されている. また，圧密後は波長1 $0.5 \mu \mathrm{m}$ 部分で水平断面のパワ 一スペクトルに小さいピークが確認でき，この測定倍率 （400倍程度）では人工モデル（やすり）と同様に, 断
面にある程度一定な波長を持った凹凸が現れているもの と考えられる.

方法2による結果を空気乾燥試料, 凍結乾燥試料につ いて，それぞれ図ー13および図－14に示す，どの試料も 周波数領域に関係なく, 測定倍率が大きくなるほど，パ ワースペクトル総和の值が小さくなる．これは，測定倍 率が大きくなるほど測定される凹凹自体が小さくなるた めである。

空気乾燥試料の圧密前では, 不撹乱試料のパワースペ クトル総和が再構成試料に比べて大きく, 構造の粗い試 料であることが示されている. 水平断面と鉛直断面を比 較すると, 測定倍率100倍と200倍では水平断面の值が低 く, 配向的な構造であることを示しているが, 全体的に はほぼ等しい值を示しており, 等方的な構造に近いもの と考えられる. 一方の再構成試料も測定倍率が大きくな るほど水平断面と鉛直断面の差が大きくなっているが, 不撹乱試料と比較すると配向的な構造であることが明確 

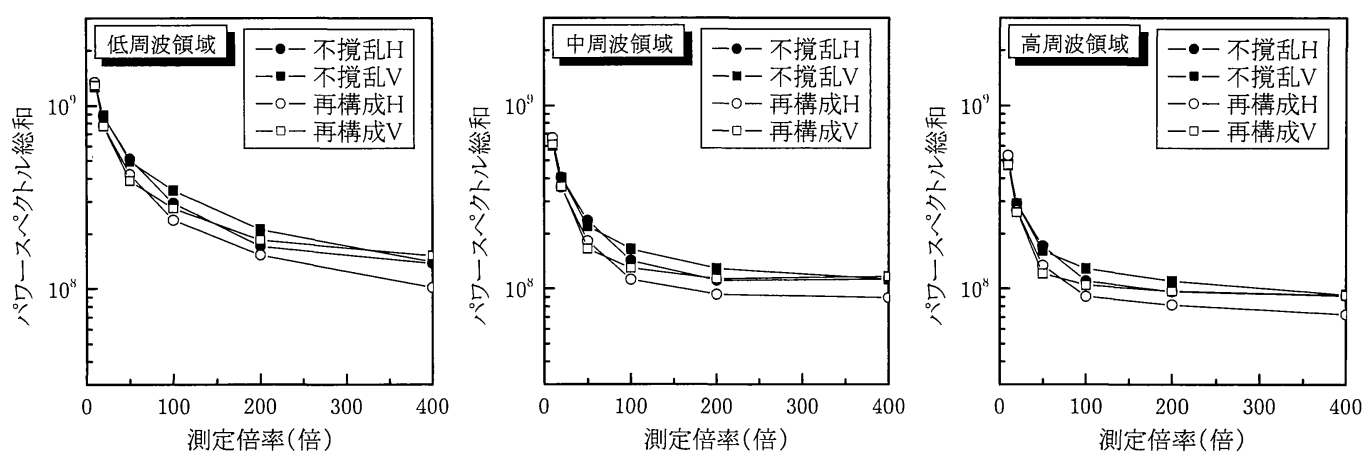

(a) 圧密前
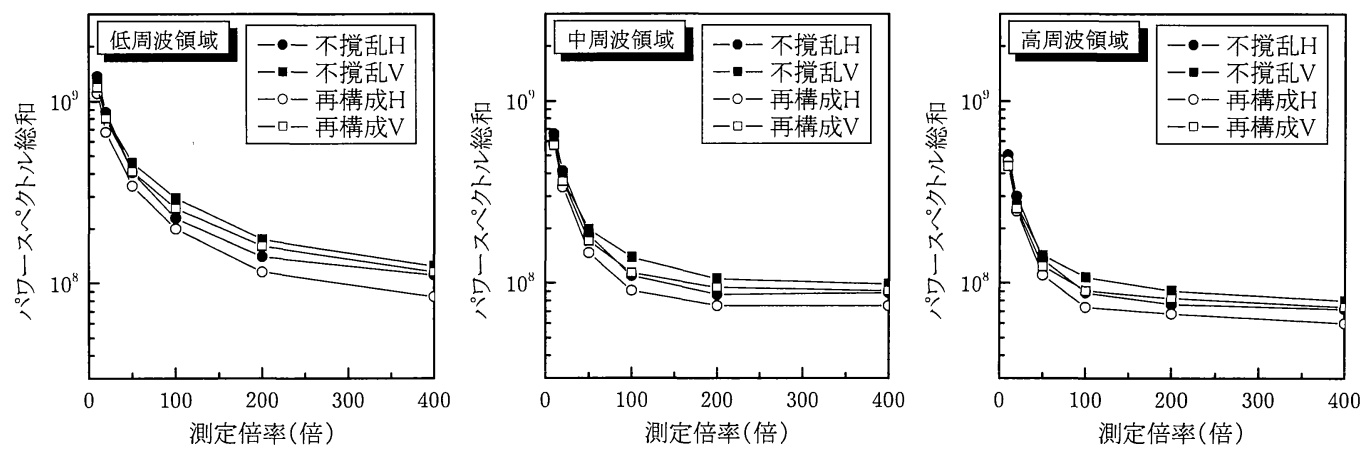

(b) 圧密後

図-13 方法 2 にる二次元フーリエ解析結果（空気乾燥試料）

に示される結果となっており，両試料で構造が異なるこ とが示されている.

圧密後はやはりどちらの試料もパワースペクトル総和 が全体的に下がる傾向にあり，水平断面の減少量が大き いことから，圧密前に比べると不撹乱試料，再構成試料 ともに水平断面が平坦で鉛直断面が粗い配向的な構造に 変化していることが明確に示される結果となっている. また，フラクタル次元と同様に不撹乱試料と再構成試料 とで完全な一致は見られない.

凍結乾燥試料の結果は空気乾燥試料に比べて，パワー スペクトル総和が著しく減少し，圧密前では不撹乱試料 と再構成試料とでほぼ同じような值が得られるため, 試 料の構造の差異があまり見られないという結果となった. 一方で, 圧密後のパワースペクトル総和を見ると, 空気 乾燥試料と比べて水平断面と鉛直断面の差が顕著に現れ ており，かなりはっきりと配向的な構造であることが示 されている。

凍結乾燥試料の場合，試料のペッド構造にほぼ無関係 に割れることによって平坦な断面が得られるため, 空気 乾燥試料に比べてペッドの回に隠れた粒子そのものに よる凹凹がかなりはっきりと現れやすくなることが考え
られる.しかしながら，ペッド構造に無関係に割れるこ とにより，不擋乱試料と再構成試料といった試料の構造 の違いは小さくなるため，これらを定量的に示す場合に 凍結乾燥法による試料はあまり適していないことが今回 の結果からは判断される.

以上から，各定量化手法は測定倍率の影響を大きく受 けるものの，表現方法の違いこそあれ，ほぼ同じような 傾向を示す結果が得られた．自然粘土に対しては，今回 の解析では測定倍率200倍前後で圧密前後の構造変化を 適切に得ることができる結果となった．また，微視構造 の評価には, 圧密前後の構造の変化が明確に現れやすく, 解釈が容易な二次元フーリエ変換の方法2を用いるのが 現時点では最適であると考えられる。

凍結乾燥試料は空気乾燥試料に比べて平坦な断面が得 られ，定量化による值も大きく減少する．一方で，空気 乾燥試料と比較すると，定量化解析によって試料の構造 の差異が小さくなるという結果が得られる.このことに ついては, 測定試料の割れ方や，体積膨張あるいは乾燥 収縮の影響など様々な要因が考えられるものの，少なく とも乾燥方法によって, 試料の断面形状が明確に異なる 

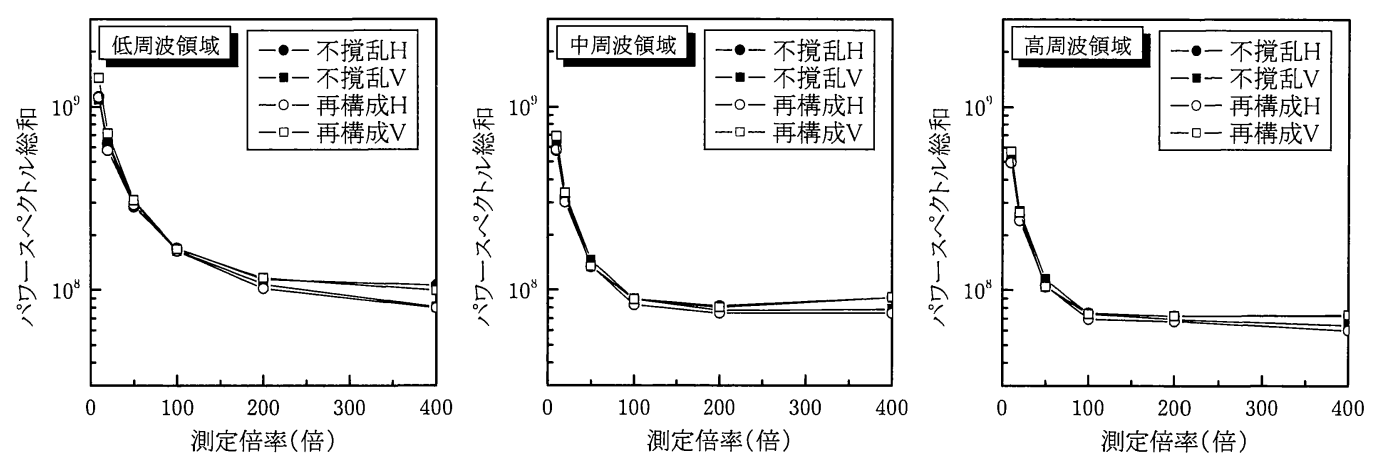

(a) 圧密前
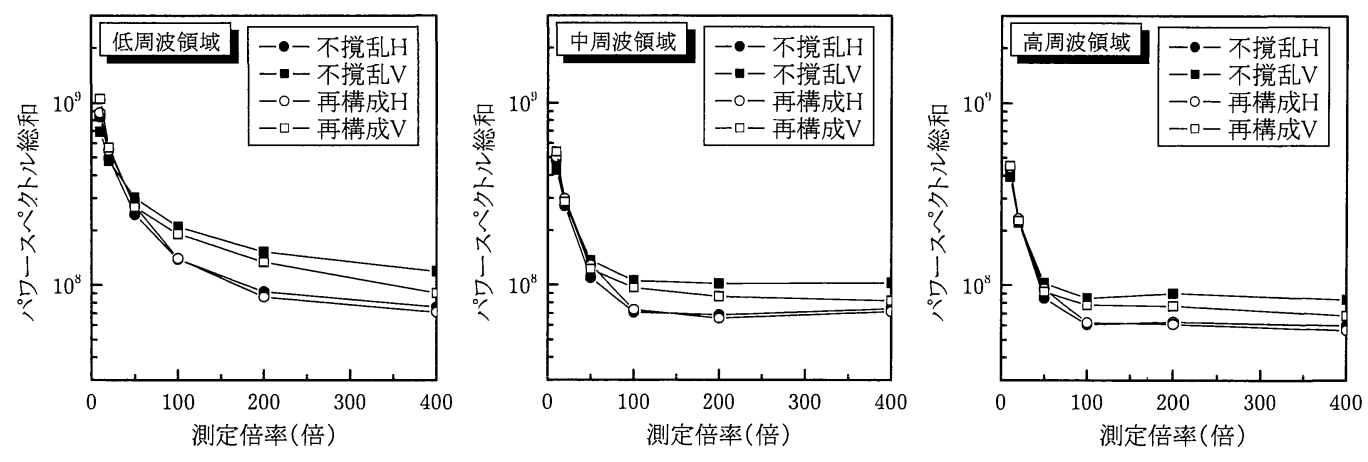

(b) 圧密後

图一-14 万法 2 によ二次元フーリエ解析結果 (凍結乾燥試料)

ことを示しており，今後も様々な観点から研究を進める 必要がある。

\section{5. まとめ}

本研究では，フラクタル次元と二次元フーリエ変換の 2つの定量化手法を用いて有楽町層粘土の微視構造の定 量的評価を行った. 主な結論は以下の通りである.

(1)不撹乱試料は再構成試料に比べて圧縮性が大きく， 顕微鏡写真でも閒隙が大きい粗い断面であることが読 み取れる.また, 珪藻等の不純物を多く含んだ試料で あることが確認された. 一方で, 再構成試料は間隙が 小さくほぼ均一な断面が得られており, 間隙が小さく 圧縮性が小さいことが顕微鏡観察から確認された。

(2)フラクタル次元および二次元フーリエ変換により, 不 擋乱試料は水平断面と鉛直断面がほぼ等しい等方的な 構造であることが定量的に示された．また，間隙が大 きく構造が発達した不擋乱試料が相対的に再構成試料 よりも定量化による值が大きく綿毛構造に近い構造で あるといえる，再構成試料は，水平断面が鉛直断面に
比べて平坦な配向構造に近い構造であることが示され た.

(3)圧密後は両試料とも水平断面の定量化による值が大き く減少し（平坦化し），より配向的な構造へと変化す る.また, 圧密前後の構造変化が激しい不擋乱試料の 值の変化が相対的に大きくなる．ただし，両試料の圧 密後の值に完全な一致は見られず，不擋乱試料は再構 成試料よりも若干大きい值をとる。これは不撹乱試料 が，圧密後もある程度の粒子間結合力を維持している ためであると考えられる.

(4)フラクタル次元と二次元フーリエ変換の手法は互いに 関連性を有しているため, 解析条件をそろえることで 複合的な評価を行うことが可能である.これらの手法 から得られる值を相対的な評価に用いることで, 粘土 の微視構造の変化を定量的に評価することができる. 中でも二次元フーリエ変換の方法2の手法は, 他の手 法に比べて構造の差異が顕著に示されるため, 自然粘 土に対してかなり適用性が高い手法であると考えられ る. とくに測定倍率200倍前後であれば圧密前後の構 造変化もほぼ定量的に示すことができる.

(5)凍結乾燥法の試料は, 空気乾燥法の試料に比べて非常 
に平坦な断面が得られ, 定量化による值が空気乾燥試 料に比べて大きく減少する，その一方で, 試料表面の 構造の差異が空気乾燥試料に比べて小さく観測される ため, 空気乾燥試料と凍結乾燥試料とでは定量的評価 が大きく異なる．今回の検討結果では，空気乾燥法が 粘土の微視構造をよりよく表現するものと判断される が, この点については, 走査型顕微鏡による観察やポ ロシメーター試験など, 様々な視点から今後議論を深 めていく必要がある.

今後さらに研究を深めることにより, 圧縮特性・圧密 特性, さらには強度・変形特性などの粘土の諸特性と, 微視構造を定量化した指数との相関性について評価を行 える可能性があり, 定量化指数がより実用性の高いもの になり得るものと考えられる。

\section{参考文献}

1）森脇武夫, 和田陽子：圧密時の温度環境が粘土の微視的構 造と力学特性に及ぼす影響, 粘土地盤における最新の研究と 実際一微視的構造の観察から長軟弱埋立て地盤対策技術まで 一に関するシンポジウム，pp. 41-46, 2002.

2）風間秀彦 : 粘性土の微視的構造と圧密・せん断特性に関す る研究, 埼玉大学博士論文, 1996.

3）姜敏秀, 土田孝 : ポロシメーター試験における洪積粘土の 圧密特性と間隙径分布の関係，第47回地盤工学シンポジウム, pp. 113-120, 2002.

4）竹内正洋，福江正治 : 自生釷物からみた堆積土の骨格構造, 粘土地盤における最新の研究と実際一微視的構造の観察から 長軟弱埋立て地盤対策技術までーに関するシンポジウム, pp. 25-28, 2002.

5）重松宏明：年代効果を受けた自然堆積土の微視的構造と力 学挙動の解明, 岐阜大学博士論文, 2002.

6）鬼塚克忠, 根上武仁: 有明粘土の微視的構造について, 地 盤工学会「高温環境と土」シンポジウム発表論文集, pp. 113-118, 1997.

7）利藤房男, 大向直樹, 田中洋行，田中正典 : 洪積粘土の圧 密に伴う微視構造の変化，土木学会論文集，№. 701/III-58, pp. 331-341, 2002.

8）引屋敷英人，渡部要一：高含水比状態における粘土の微視 構造, 第35回地盤工学研究発表会, pp. 741-742, 2000.

9）廣野哲郎他 : 走查型電子顕微鏡観察による含水未固結粘土 の凍結乾燥法後およびオーブン乾燥後の微細組織の比較, 地 質学䧱誌，第106巻，第12号，pp.909-912，2000.

10）松尾新一郎，嘉門雅史 : 粘土の構造に関する用語について, 土と基礎，Vol24，№.1，pp. 5964， 1976.

11）地盤工学会 : 粘土地盤におけ最新の研究と実際一微視的 構造の観察から長軟弱埋立て地盤対策技術までーに関するシ ンポジウム, pp. 355-357, 2002.

12）足立格一郎，宮永慎也他 : 粘土の微視構造のフラクタル次 元解析, 土木学会第56回年次学術講演概要集, III-A165, pp. 330-331， 2001.

13）三橋博三，梅岡俊治, 三浦悟 : セメント硬化体の破面解析 に関する基礎的研究, 日本建築学会構造系論文報告集, 第 445号, pp. 19-24, 1993.

14）大栗基樹 : 皮膚形状計測と皮膚の老化に関する研究，芝浦 工業大学博士論文, 2000.

15）兼松学, 北垣亮馬, 野口貴文, 友澤史紀 : 二次元フーリエ 変換によるコンクリートの污れの評価手法に関する基礎的研 究，コンクリート工学年次論文集, Vol.22-1, pp. 211-216, 2000.

(2003.12. 25 受付)

\section{STUDY ON THE QUANTITATIVE ANALYSIS OF THE MICRO-STRUCTURE OF CLAY USING TOKYO ALLUVIAL CLAY}

\section{Jun KODAMA and Kakuichiro ADACHI}

Difference in the micro-structure of clay can be shown qualitatively by the electron microscope, but there are few researches that have evaluated it quantitatively. Studies are conducted on Tokyo Alluvial Clay, and the Color Laser 3D Profile Microscope was used. Fractal dimension and Fourier transformation were employed for the analysis. After the measurement and analysis on the undisturbed and reconstituted samples, the present study indicate quantitatively the difference in the micro-structure of clays. Changes in the micro-structure of clay by the consolidation are also detected. Moreover, difference of the results by the sample preparation process between air-drying and freeze-drying is discussed quantitatively. 